Research Article

\title{
Stiff Substrates Enhance Endothelial Oxidative Stress in Response to Protein Kinase C Activation
}

\author{
Rebecca Lownes Urbano, ${ }^{1}$ Swathi Swaminathan, ${ }^{2}$ and Alisa Morss Clyne $\mathbb{C}^{1,2}$ \\ ${ }^{1}$ Mechanical Engineering and Mechanics, Drexel University, Philadelphia, PA, USA \\ ${ }^{2}$ Biomedical Engineering, Science and Health Systems, Drexel University, Philadelphia, PA, USA \\ Correspondence should be addressed to Alisa Morss Clyne; asm67@drexel.edu
}

Received 1 October 2018; Revised 28 January 2019; Accepted 19 February 2019; Published 14 April 2019

Academic Editor: Estefanía Peña

Copyright (C) 2019 Rebecca Lownes Urbano et al. This is an open access article distributed under the Creative Commons Attribution License, which permits unrestricted use, distribution, and reproduction in any medium, provided the original work is properly cited.

\begin{abstract}
Arterial stiffness, which increases with aging and hypertension, is an independent cardiovascular risk factor. While stiffer substrates are known to affect single endothelial cell morphology and migration, the effect of substrate stiffness on endothelial monolayer function is less understood. The objective of this study was to determine if substrate stiffness increased endothelial monolayer reactive oxygen species (ROS) in response to protein kinase $\mathrm{C}$ (PKC) activation and if this oxidative stress then impacted adherens junction integrity. Porcine aortic endothelial cells were cultured on varied stiffness polyacrylamide gels and treated with phorbol 12-myristate 13-acetate (PMA), which stimulates PKC and ROS without increasing actinomyosin contractility. PMA-treated endothelial cells on stiffer substrates increased ROS and adherens junction loss without increased contractility. ROS scavengers abrogated PMA effects on cell-cell junctions, with a more profound effect in cells on stiffer substrates. Finally, endothelial cells in aortae from elastin haploinsufficient mice $(E l n+/-)$, which were stiffer than aortae from wild-type mice, showed decreased VE-cadherin colocalization with peripheral actin following PMA treatment. These data suggest that oxidative stress may be enhanced in endothelial cells in stiffer vessels, which could contribute to the association between arterial stiffness and cardiovascular disease.
\end{abstract}

\section{Introduction}

Due to the highly mechanical nature of the cardiovascular system, cardiovascular disease has long been accepted as both a biomechanical and biochemical disease. Arterial stiffness, which increases with hypertension and aging among others, is an independent predictor of cardiovascular risk [1-3]. Arteries reversibly stiffen when smooth muscle cells contract and irreversibly stiffen as elastin is degraded and collagen increases [4-9]. Stiff arteries have long been known to contribute to cardiovascular mortality by increasing cardiac afterload [10]; more recently, stiff arteries have also been shown to contribute to endothelial dysfunction, an initiating step in atherosclerosis [11-13]. In vitro, endothelial monolayers on stiff polyacrylamide (PA) gels were more permeable $[12,14,15]$. In animal models, endothelial permeability was elevated in stiffened aortae from older mice [12]. Mesenteric arteries from elastin haploinsufficient
$(E l n+/-)$ mice had enhanced angiotensin-induced vasoconstriction and impaired endothelium-dependent vasodilation [13], although aortae from these same animals do not [16]. In human subjects, endothelial flow-mediated vasodilation was inversely correlated with aortic stiffness $[17,18]$. Thus, arterial stiffness alone may contribute to cardiovascular risk by altering critical endothelial functions.

However, cardiovascular risk factors rarely occur in isolation but rather cluster in certain individuals. Little is known about how arterial stiffness interacts with other cardiovascular risk factors such as diabetes and inflammation. Both hyperglycemia and inflammatory cytokines such as tumor necrosis factor- $\alpha$ (TNF- $\alpha$ ) increase endothelial cell oxidative stress due to increased production and decreased scavenging of reactive oxygen species (ROS). Elevated ROS have been implicated in both hypertension and atherosclerosis pathogenesis [19]. ROS are a family of highly reactive oxygencontaining molecules, including superoxide $\left(\mathrm{O}_{2}{ }^{-}\right)$, hydrogen 
peroxide $\left(\mathrm{H}_{2} \mathrm{O}_{2}\right)$, hydroxyl radical $(\mathrm{OH})$, and peroxynitrite $\left(\mathrm{ONOO}^{-}\right)$, which play an important role in many signaling pathways, such as cell proliferation, survival, and metabolism [20]. Superoxide is produced by the mitochondrial electron transport chain, as well as through protein kinase C- (PKC-) induced NADPH oxidase upregulation and activation [21-23]. NADPH oxidase assembly at the cell membrane requires Rac, which is enhanced by substrate stiffness [24].

The effect of arterial stiffness on endothelial ROS production in response to an external stimulus such as hyperglycemia or TNF- $\alpha$ has not yet been investigated. However, these risk factors also activate many other endothelial cell signaling pathways. Therefore, to isolate substrate stiffness effects on endothelial ROS production, we used phorbol 12-myristate 13-acetate (PMA), a PKC activator widely used to stimulate ROS production in vitro. In previous studies, PMA treatment increased endothelial monolayer permeability but did not increase actinomyosin contractility, as measured by silicon substrate wrinkling, myosin light chain (MLC) phosphorylation, or MLC kinase activation [25, 26]. Phorbol esters may instead induce barrier loss through intermediate filament or actin cytoskeleton reorganization [27-29]. Thus, PMA enables investigation of substrate stiffness effects on ROS production without stimulating actinomyosin contractility.

We hypothesized that stiff substrates would increase endothelial ROS in response to PMA, resulting in actin fiber formation and cell-cell junction loss. We used varied stiffness PA gels to study PMA-induced endothelial ROS, actin fiber formation, and adherens junction loss. Abdominal aortae from wild-type (WT) and Eln+/- mice were treated with PMA ex vivo and imaged en face. We now show that substrate stiffness enhances PMA-induced oxidative stress in endothelial monolayers in vitro and alters actin fiber reorganization and adherens junction morphology both in vitro and ex vivo.

\section{Materials and Methods}

2.1. Animals. All experiments were performed according to protocols approved by the Drexel University College of Medicine Animal Studies Committee. Eln+/- mice were generated as previously described [30]. 8-12-week-old WT and Eln+/- mice of both sexes, backcrossed several generations into the C57BL/6 background (Charles River), were used. All mice were genotyped to confirm elastin heterozygosity, and decreased elastin lamellae thickness was confirmed in select animals by immunohistochemistry. Mice were provided access to food and water ad libitum at $22^{\circ} \mathrm{C}$ and a 12 -hour light/dark cycle.

2.2. Atomic Force Microscopy (AFM). AFM was used to quantify aortic stiffness in wild-type (WT) and Eln+/- mouse aortae. The aorta was dissected and transferred to ice-cold HEPES buffer $(140 \mathrm{mM} \mathrm{NaCl}, 5 \mathrm{mM} \mathrm{KCl}, 1 \mathrm{mM} \mathrm{CaCl}$, $1.2 \mathrm{mM} \mathrm{MgSO}_{4}, 1.2 \mathrm{mM} \mathrm{Na}_{2} \mathrm{HPO}_{4}, 10 \mathrm{mM}$ HEPES, $10 \mathrm{mM}$ sodium acetate, and $5 \mathrm{mM}$ glucose, $\mathrm{pH} 7.4$ ). Excess tissue was cleaned from the outside of the vessel, and the vessel was cut open longitudinally to expose the endothelium. Each aorta was cut into four segments-two thoracic segments and two abdominal segments-producing four samples per aorta. Samples were carefully mounted, the endothelium facing up, on a coverslip using Loctite 401 medical grade adhesive (Henkel) and submersed in PBS. The endothelium was removed by gentle scraping with a cotton-tip applicator, based on a published protocol [31]. Subendothelial stiffness was determined by AFM using precalibrated cantilevers (spring constants between 0.10 and $0.17 \mathrm{~N} / \mathrm{m}$ ) with $10 \mu \mathrm{m}$ spherical tips. Between three and nine indentations were made at different locations along each sample. The forceindentation curve for each indentation was fit to the Hertz model down to $200 \mathrm{~nm}$ indentation using a custom MATLAB code to produce a stiffness value [32]. Subendothelial stiffness was calculated as the average of the individual stiffness values of each sample.

\subsection{Cell Culture and Polyacrylamide (PA) Gel Sample} Preparation. Primary porcine aortic endothelial cells (PAEC) were isolated by the collagenase dispersion method and cultured in low glucose Dulbecco's modified Eagle's medium (DMEM, Corning) supplemented with $5 \%$ fetal bovine serum (FBS, HyClone), $1 \%$ glutamine, and $1 \%$ penicillinstreptomycin (Invitrogen). Cells were used up to passage 9.

6,14 , or $29 \mathrm{kPa}$ was selected for the PA gel stiffnesses based on the subendothelial stiffnesses measured in WT and Eln+/- mouse aorta (Figure 1). PA gels were prepared following well-established protocols [33, 34]. Briefly, a bottom coverslip was made hydrophilic by consecutive incubations with $0.1 \mathrm{M}$ sodium hydroxide ( $\mathrm{NaOH}$, Sigma-Aldrich), 3-aminopropyltrimethoxysiliane (3-APTES, Sigma-Aldrich), and $0.5 \%$ glutaraldehyde (Electron Microscopy Sciences). A top coverslip was made hydrophobic by applying SurfaSil (1,7-dichloro-octamethyltetrasiloxane, Thermo Scientific). A solution containing varying amounts of $40 \%$ acrylamide and $2 \%$ bisacrylamide (Bio-Rad) was prepared based on the desired gel stiffness (Table 1). Ammonium persulfate (Bio-Rad) and tetramethylethylenediamine (TEMED, Bio$\mathrm{Rad}$ ) were added to the acrylamide/bisacrylamide solution to achieve final concentrations of $0.1 \% w / v$ and $0.3 \% v / v$, respectively, initiating gel polymerization. Polymerizing gel solution was added to the bottom coverslip, and the top coverslip was quickly inverted onto the polymerizing gel to create a flat surface. After gel formation, the top coverslip was removed. Elastic modulus was confirmed by AFM. To make the surface adhesive to cells, the gel was UV-activated using sulfo-SANPAH (Thermo Fisher) in dimethyl sulfoxide (DMSO, Fisher Scientific) and $50 \mathrm{mM}$ HEPES buffer and then incubated with $100 \mu \mathrm{g} / \mathrm{mL}$ type I collagen (BD Biosciences) at $37^{\circ} \mathrm{C}$ for 3 hours at room temperature or at $4^{\circ} \mathrm{C}$ overnight. The collagen-coated gel was rinsed in sterile phosphate-buffered saline (PBS) and UV-sterilized prior to cell seeding.

PAEC were seeded on collagen-coated PA gels in phenol red-free DMEM and cultured to confluence for three days in a growth medium. Cells were then serum-starved overnight in phenol red-free DMEM containing 1\% FBS, $1 \%$ glutamine, and $1 \%$ penicillin-streptomycin. After serum starvation, cells were left untreated or treated with $1 \mu \mathrm{M}$ PMA for varying 


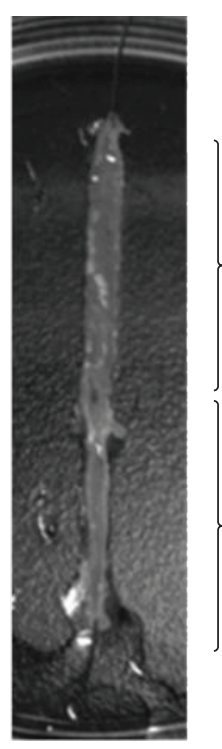

(a)

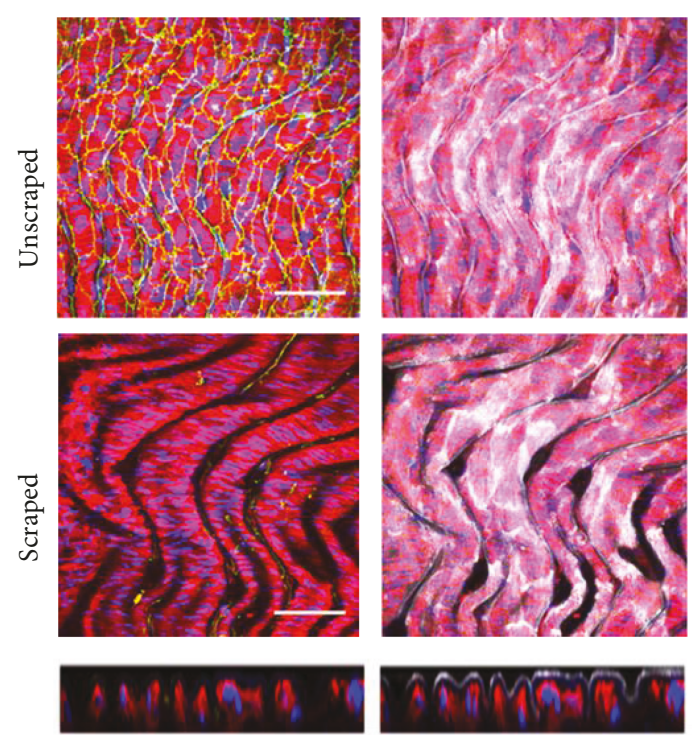

(b)

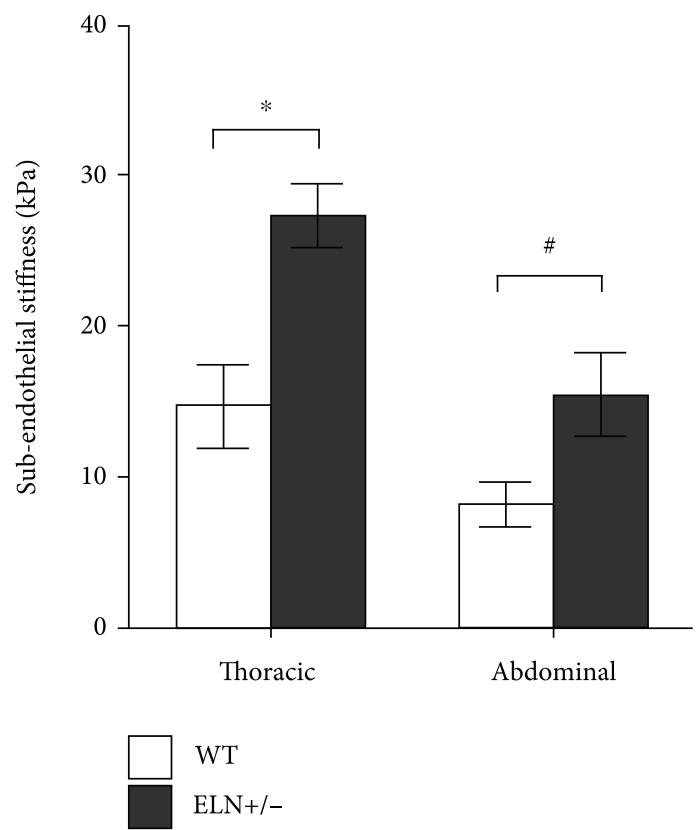

(c)

FIGURE 1: Subendothelial stiffness increased in the thoracic and abdominal aortae of Eln $+/-$ mice. (a) Longitudinally dissected mouse aorta opened to expose the endothelial surface. (b, top) Unscraped aorta showing the intact endothelium via $\beta$-catenin (green), cell structure using actin (red) and nuclei (blue), and the subendothelial matrix using collagen IV (white). Artery is shown en face. (b, bottom) Scraped aorta showed that the endothelium was removed since no $\beta$-catenin (green) was observed. The subendothelial matrix (collagen IV, white) remained intact and contiguous both en face and in cross section (smaller images). Scale bar $=50 \mu \mathrm{m}$. (c) Subendothelial stiffness of aortae from WT and Eln+/- mice. Thoracic and abdominal aortic sections were indented by AFM using a silicon nitride cantilever with a $10 \mu \mathrm{m}$ spherical tip to measure subendothelial stiffness $\left({ }^{*} p<0.01\right.$ and ${ }^{\#} p<0.05$ by Student's $t$-test). Three aortae were tested for each condition.

TABle 1: Acrylamide and bisacrylamide concentrations used to create varying elastic modulus PA gels.

\begin{tabular}{lcc}
\hline Acrylamide & Bisacrylamide & Elastic modulus \\
\hline $7.5 \%$ & $0.05 \%$ & $6 \mathrm{kPa}$ \\
$10 \%$ & $0.1 \%$ & $14 \mathrm{kPa}$ \\
$10 \%$ & $0.3 \%$ & $29 \mathrm{kPa}$ \\
\hline
\end{tabular}

durations. In some cases, endothelial monolayers were pretreated with ROS scavengers $(4 \mathrm{mM}$ N-acetyl cysteine or $50 \mathrm{mM}$ sodium pyruvate, Sigma) for 1 hour prior to PMA.

2.4. ROS Assay. ROS were measured using 5-(and-6)chloromethyl-2', $7^{\prime}$-dichlorodihydrofluorescein diacetate (CM- $\left.\mathrm{H}_{2} \mathrm{DCFDA}\right)$, which passively diffuses into cells where it is cleaved by intracellular esterases and then oxidized by 
ROS to yield a fluorescent adduct. $100 \mu \mathrm{M}$ tert-butyl hydroperoxide (tBHP), which produces intracellular hydrogen peroxide, was the positive control. After PMA or tBHP treatment, samples were rinsed with warmed HBSS buffer (0.137 M NaCl, $5.4 \mathrm{mM} \mathrm{KCl}, 0.25 \mathrm{mM} \mathrm{Na} \mathrm{HPO}_{4}, 5.6 \mathrm{mM}$ glucose, $0.44 \mathrm{mM} \mathrm{KH}_{2} \mathrm{PO}_{4}, 1.3 \mathrm{mM} \mathrm{CaCl}_{2}, 1.0 \mathrm{mM} \mathrm{MgSO}$, and $4.2 \mathrm{mM} \mathrm{NaHCO} 3$ ). $25 \mu \mathrm{M} \mathrm{CM}-\mathrm{H}_{2} \mathrm{DCFDA}$ in phenol red-free DMEM was added to each sample and incubated for 25 minutes at $37^{\circ} \mathrm{C}$, protected from light. To label nuclei, bisbenzimide $(0.2 \mu \mathrm{g} / \mathrm{mL}$, Thermo Fisher) was added to each sample for an additional 5 minutes. After thorough washing in HBSS buffer, samples were immersed in warmed phenol red-free DMEM and imaged in an Olympus Fluoview 1000 microscope as confocal $z$-stacks ( $1 \mu \mathrm{m}$ step size).

2.5. Confocal Microscopy and Image Analysis. Endothelial cells on PA gels were imaged by confocal microscopy and analyzed using MATLAB. In vitro cell samples were rinsed once with ice-cold PBS and fixed with ice-cold 4\% paraformaldehyde. Samples were then permeabilized with $0.2 \%$ Triton X-100 in PBS for 15 minutes and blocked with 1\% bovine serum albumin (BSA) in PBS for 1 hour at room temperature. After fixation, mouse aortae were simultaneously blocked and permeabilized in PBS containing 1\% BSA and $0.3 \%$ Triton X-100. Endothelial cells on PA gels were labeled with primary antibodies for VE-cadherin (1:200, Santa Cruz), $\beta$-catenin $(1: 200$, Thermo Fisher $)$, or pMLC $(1: 200$, Cell Signaling) in $1 \%$ BSA in PBS overnight at $4^{\circ} \mathrm{C}$. After several rinses with $\mathrm{PBS}$, samples were then incubated with the appropriate Alexa Fluor 488 or 633 (1:200, Thermo Fisher) secondary antibody, rhodamine phalloidin (16.5 nM, Invitrogen), and bisbenzimide $(0.2 \mu \mathrm{g} / \mathrm{mL})$ for 1 hour at room temperature, protected from light. Samples were rinsed twice with PBS and mounted in $1: 1$ glycerol: PBS. Confocal $z$-stacks were acquired for all samples with either a 0.25 or $0.5 \mu \mathrm{m}$ step size (for in vitro and ex vivo samples, respectively) using an Olympus Fluoview 1000 confocal microscope at 60x magnification.

A custom MATLAB code was created to quantify ROS and pMLC. The background was subtracted using a $50 \times 50$ pixel area. Images were then binarized using the same threshold as determined using Otsu's method, which calculates a threshold based on pixel intensity distribution [35]. Noise was removed from binarized images by excluding small objects (less than 9 pixels for ROS, less than 30 pixels for pMLC). The number of remaining pixels with intensities above the threshold ("positive" pixels) was counted for each image. Three images per sample were quantified using this method and averaged to quantify ROS or pMLC in each sample.

2.6. PKC Activity Assay. After treatment, cells on PA gels were quickly rinsed with ice-cold PBS and inverted onto $50 \mu \mathrm{L}$ lysis buffer (20 mM MOPS, $50 \mathrm{mM} \beta$-glycerophosphate, $50 \mathrm{mM}$ sodium fluoride, $1 \mathrm{mM}$ sodium orthovanadate, $5 \mathrm{mM}$ EGTA, $2 \mathrm{mM}$ EDTA, 1\% NP40, $1 \mathrm{mM}$ dithiothreitol, $1 \mathrm{mM}$ benzamidine, $1 \mathrm{mM}$ phenylmethanesulfonyl fluoride, $10 \mu \mathrm{g} / \mathrm{mL}$ leupeptin, and $10 \mu \mathrm{g} / \mathrm{mL}$ aprotinin) for 10 minutes at $4^{\circ} \mathrm{C}$. Lysed cells were then scraped from the gel substrates, collected in prechilled Eppendorf tubes, and centrifuged at $4^{\circ} \mathrm{C}$ for 15 minutes at $13,000 \mathrm{rpm}$. The supernatant was collected, and the protein concentration was determined by BCA assay (Thermo Fisher). PKC activity was quantified in control or treated cell lysates using an ELISA-based PKC kinase assay (Enzo) as per the manufacturer's instructions. Absorbance $(450 \mathrm{~nm})$ was measured on a microplate reader (Thermo LabSystems, Multiskan Spectrum). Relative kinase activity was calculated as follows:

\section{Relative kinase activity

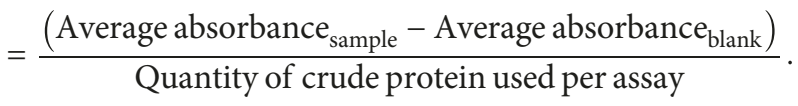

2.7. Statistical Analysis. All statistical analyses were conducted using MATLAB's statistical toolbox. Graphs represent mean \pm standard deviation. Multiple groups were compared using either two-way or $n$-way ANOVA with post hoc Tukey-Kramer test, and two groups were compared by Student's $t$-test. Within each PKC assay, conditions were tested in duplicate. For ROS measurement, conditions were tested in triplicate. All experiments were conducted at least two times, with at least three samples per condition.

\section{Results}

3.1. Subendothelial Stiffness Was Higher in Eln+/- as Compared to WT Mouse Aorta. Macroscale arterial stiffness, measured by pulse wave velocity or pressure myography, increases in mice genetically engineered to produce less elastin (Eln+/-) [36, 37]. However, aortic stiffness had not been characterized by atomic force microscopy in this mouse model. The longitudinally dissected mouse aorta (Figure 1(a)) shows the mounting technique and the thoracic and abdominal sections. Aortae with the intact endothelium were first labeled for $\beta$-catenin (green) to show endothelial cell-cell junctions, actin (red) and nuclei (blue) to highlight cell structure, and collagen IV (white) to view the basement membrane (Figure 1(b), top). When we removed the endothelium from the longitudinally dissected mouse aortae, we no longer observed $\beta$-catenin, confirming that cells were removed. The collagen IV layer remained intact and contiguous, indicating that the subendothelial matrix remained intact (Figure 1(b), bottom; collagen IV integrity was most clear in the cross-sectional image). However, it is possible that endothelial removal did damage the subendothelial layer, as evidenced by the spaces in the fluorescently labeled samples. We therefore repeated the atomic force microscopy in both scraped and unscraped WT mouse aortae and found no difference in aortic stiffness measurements. When aortic samples were indented by AFM, the thoracic and abdominal aortic subendothelium from Eln+/- mice was about 1.75 -fold stiffer than that of WT mice (Figure 1(c)). The thoracic aorta was consistently stiffer than the abdominal aorta in both genotypes. 

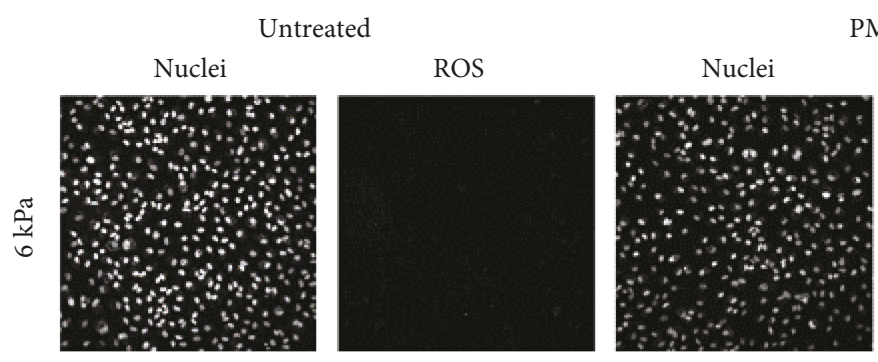

PMA
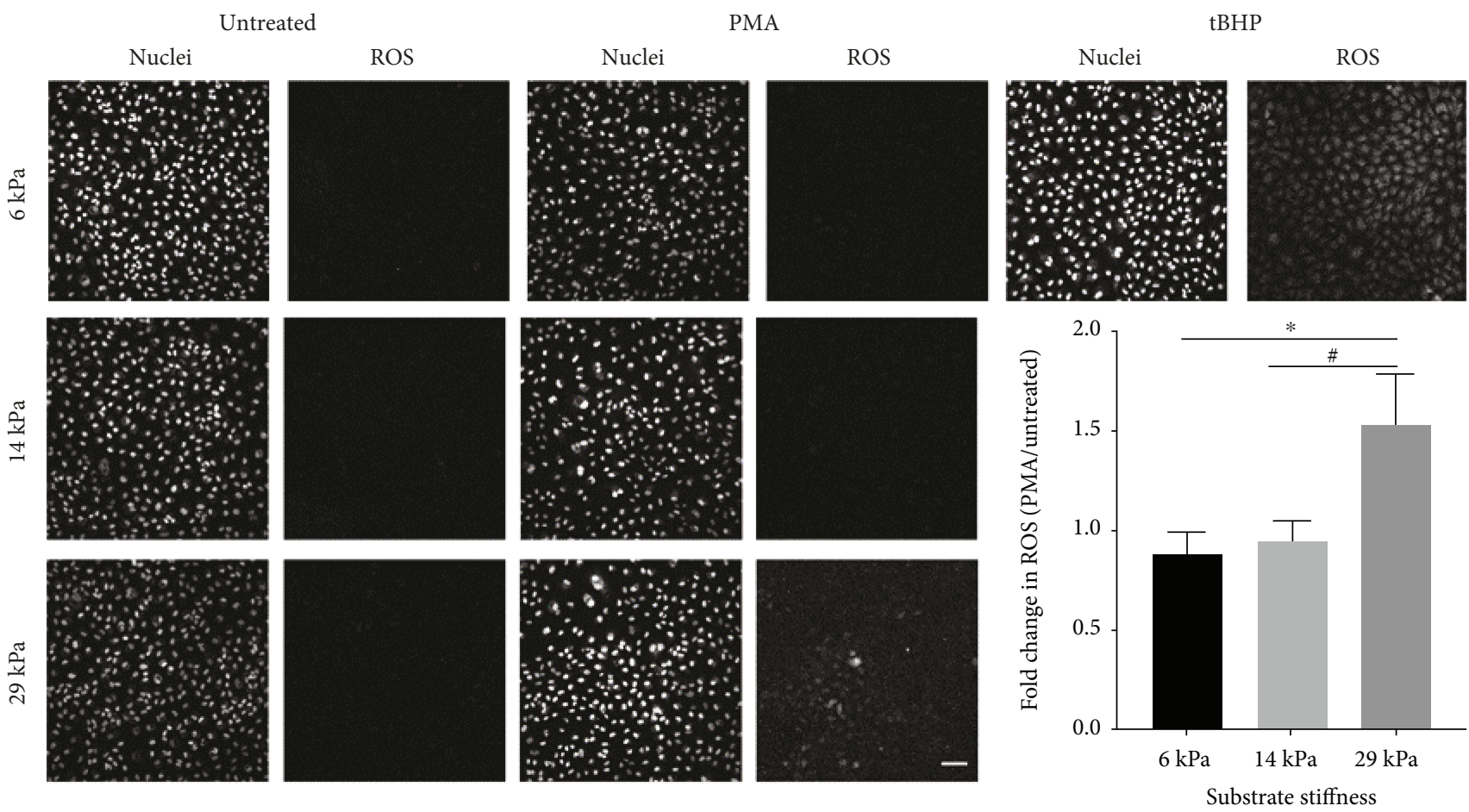

FIgURE 2: ROS increased with substrate stiffness following PMA treatment. PAEC monolayers on 6, 14, and $29 \mathrm{kPa}$ gels were treated with $1 \mu \mathrm{M}$ PMA for 10 minutes. Tert-butyl hydroperoxide (tBHP) was the positive control. Cell nuclei were labeled with Hoechst, and ROS with $\mathrm{CM}-\mathrm{H}_{2}$ DCFDA. Samples were imaged at $20 \mathrm{x}$ by confocal microscopy. Scale bar is $25 \mu \mathrm{m}$. Oxidative stress was quantified using the number of positive pixels (above the threshold) using the custom MATLAB code. PMA-treated samples were normalized to untreated samples on the same substrate stiffness. The effect of substrate stiffness was significant by one-way ANOVA $(p<0.01)$. ${ }^{\#} p<0.05$ and ${ }^{*} p<0.01$ by post hoc Tukey-Kramer test.

\subsection{PMA-Induced Increased Oxidative Stress in Endothelial} Cells on the Stiffest PA Gels. We then created 6, 14, and $29 \mathrm{kPa}$ PA gels, which correspond to aortic stiffnesses in WT and Eln+/- mice, to determine if different ROS levels were produced by PMA-treated endothelial monolayers cultured on substrates of varied stiffness. Each sample was treated with $1 \mu \mathrm{M}$ PMA for 10 minutes, based on preliminary experiments showing maximum cell viability and ROS at this dose and time, and consistently imaged by confocal microscopy. ROS were statistically similar following PMA treatment of cells on 6 and $14 \mathrm{kPa}$ gels. In addition, endothelial cells on stiff substrates did not show any baseline increase in ROS. However, in endothelial cells on $29 \mathrm{kPa}$ substrates that were treated with PMA, ROS increased by more than 50\% $(p<0.01$ compared to fold change in cells on $6 \mathrm{kPa}$ gels, Figure 2). Substrate stiffness effects on the PMA-induced fold change in ROS were also significant by one-way ANOVA $(p<0.01)$. These results demonstrate that stiffer substrates increase endothelial ROS in response to PMA.

\subsection{Endothelial Cell PKC Increased in Response to PMA} Independent of PA Gel Stiffness. PMA induces ROS production through PKC signaling $[38,39]$. We therefore measured PKC activity in PMA-treated endothelial cells on 6,14, and $29 \mathrm{kPa}$ PA gels to determine if PKC activation increased on stiffer substrates. PKC activity in PAEC increased 3-4-fold within 5 minutes of PMA treatment (Figure 3(a)). However, PKC activity in cells stimulated with PMA did not change significantly whether the cells were on soft or stiff PA gels (Figure 3(b)). Therefore, the PMA-induced differences in oxidative stress on stiffer substrates were not related to PKC activation.

3.4. Endothelial Cells Formed More Actin Stress Fibers in Response to PMA on Stiffer Gels. ROS lead to endothelial actin fiber formation [40]. PMA-stimulated cells on increasing stiffness substrates were labeled for actin fibers to determine if substrate stiffness-dependent oxidative stress increased actin fiber formation. In untreated samples, actin fibers were primarily located around the cell periphery on all substrates, although the effect was more pronounced in cells on the softest $6 \mathrm{kPa}$ gels (Figure 4(a), representative cell magnification in Figure 4(b)). Following 15 minutes of PMA treatment, actin fibers appeared in cells on the 14 and $29 \mathrm{kPa}$ gels, but not in cells on the $6 \mathrm{kPa}$ gels. This effect was even more pronounced following 30 minutes of PMA treatment, with larger stress fibers and nearly complete peripheral actin loss in endothelial cells on 14 and $29 \mathrm{kPa}$ gels. Cells on $6 \mathrm{kPa}$ gels largely retained peripheral actin with PMA treatment.

PAECs were then labeled for pMLC to determine whether ROS-induced actin stress fiber formation was associated with increased actinomyosin contractility through pMLC localization to actin stress fibers. $1 \mu \mathrm{M}$ PMA treatment for 15 or 30 minutes did not induce pMLC translocation to actin fibers or increase overall pMLC (Figure 5). In contrast, the positive control $(10 \mathrm{U} / \mathrm{mL}$ thrombin for 30 


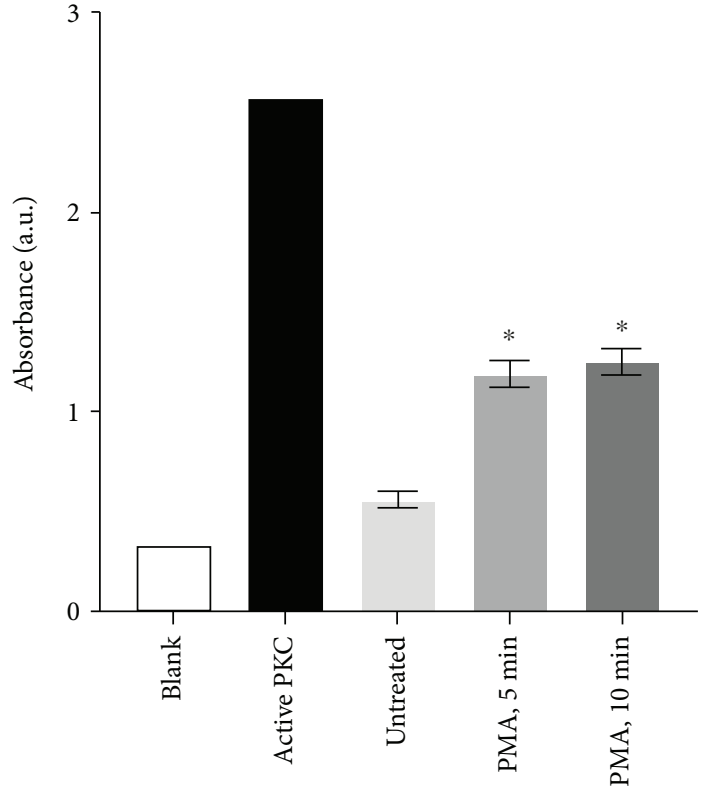

(a)

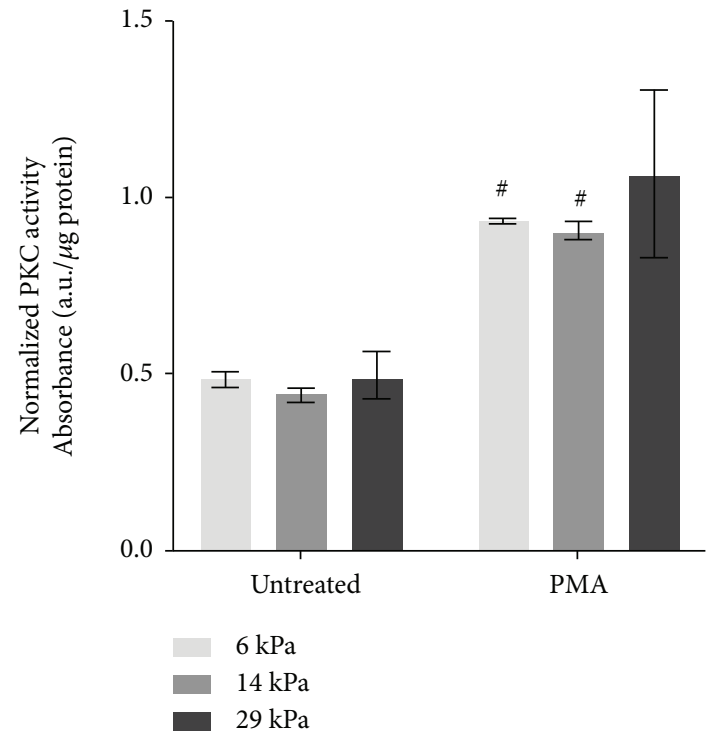

(b)

FIgURE 3: PKC activity increased with PMA independent of substrate stiffness. (a) PKC activity was measured following $1 \mu$ M PMA treatment in endothelial cells on glass substrates. Purified active PKC was the positive control. ${ }^{*} p<0.01$ compared to that untreated by Student's $t$-test. (b) PAEC monolayers on 6,14 , and $29 \mathrm{kPa}$ substrates were treated with $1 \mu \mathrm{M}$ PMA for 5 minutes. PMA was significant by two-way ANOVA $(p<0.001)$, but substrate stiffness was not significant. ${ }^{*} p<0.05$ by post hoc Tukey-Kramer test compared to that untreated.

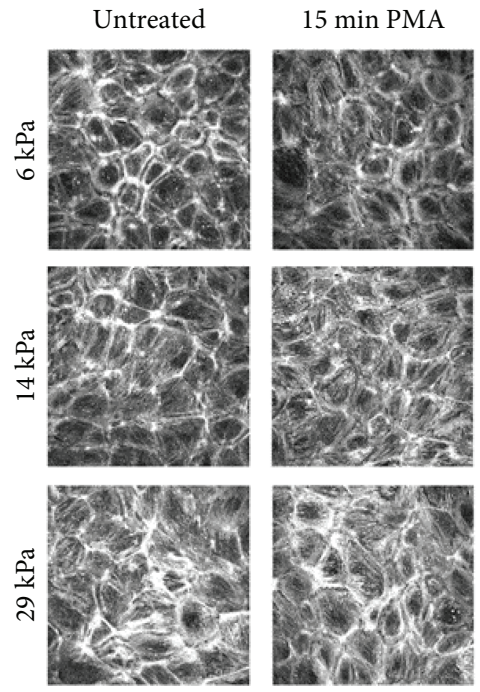

(a)
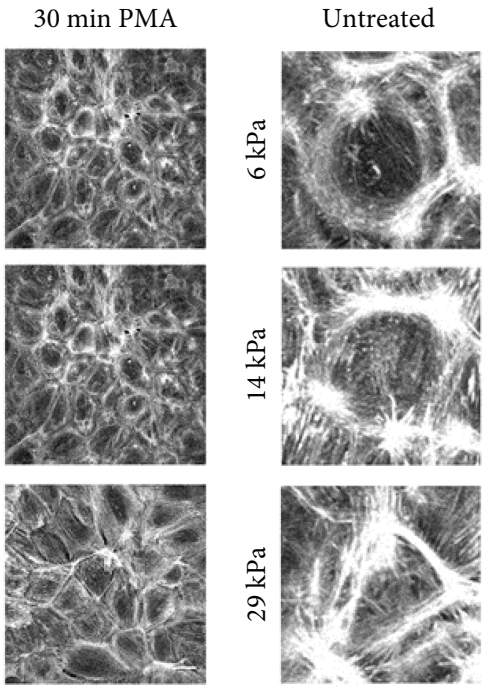

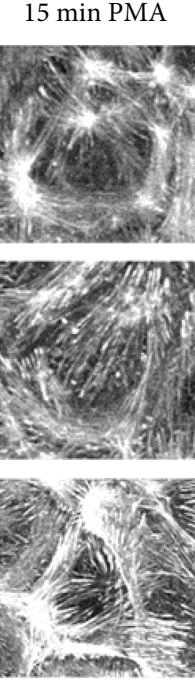

(b)

FIgURe 4: Actin stress fiber formation was greater in endothelial cells on stiffer substrates following PMA. PAEC monolayers on 6, 14, or $29 \mathrm{kPa}$ gels were treated with $1 \mu \mathrm{M}$ PMA for 15 or 30 minutes prior to fixation and immunofluorescent labeling of actin (rhodamine phalloidin). (a) Maximum intensity projection from confocal $z$-stacks at $60 \mathrm{x}$ magnification. Scale bar is $25 \mu \mathrm{m}$. (b) Magnified representative cells from (a).

minutes) increased overall pMLC approximately 14-fold, with pMLC localized along the actin fibers. These results indicate that PMA-induced actin fiber formation in cells on stiffer substrate did not correspond to actinomyosin contractility.
3.5. Adherens Junctions Became Less Reticular in Response to PMA on Stiffer Gels. ROS induce cell-cell junction loss, which has been attributed in part to adherens junction protein phosphorylation and internalization [41-43]. We therefore measured if stiff substrates exacerbate ROS-mediated endothelial 

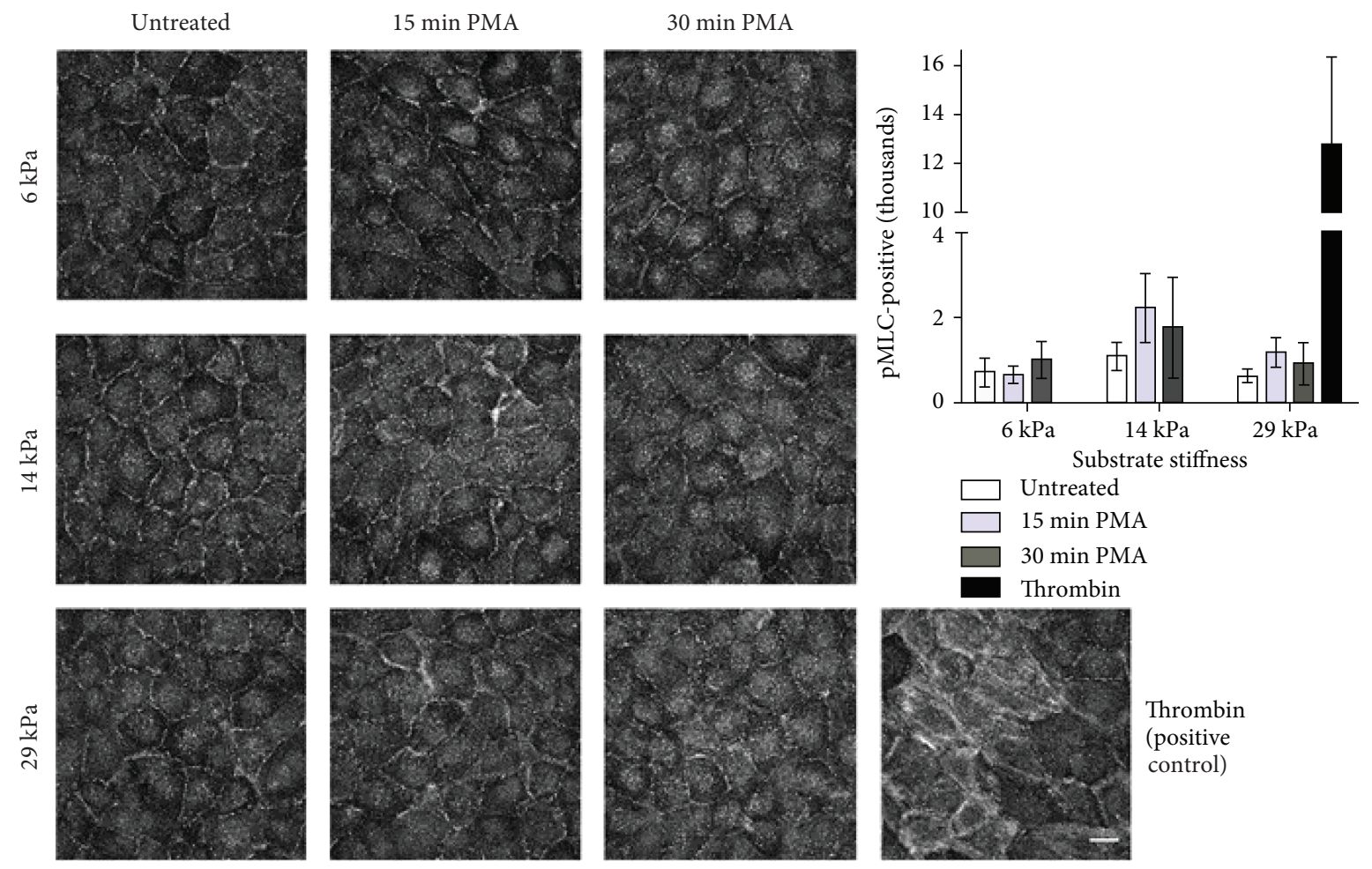

FIgURE 5: PMA treatment did not increase pMLC localization to actin stress fibers in cells on varied stiffness substrates. PAEC monolayers on 6,14 , or $29 \mathrm{kPa}$ gels were treated with $1 \mu \mathrm{M}$ PMA for 15 or 30 minutes, prior to fixation and pMLC immunofluorescent labeling. For the positive control, cells on a $29 \mathrm{kPa}$ gel were treated with $10 \mathrm{U} / \mathrm{mL}$ thrombin for 30 minutes. Images are maximum intensity projections from 60x confocal $z$-stacks. Scale bar is $25 \mu \mathrm{m}$. pMLC-positive pixels were quantified using the custom MATLAB code. Stiffness and PMA treatment were not significant by $n$-way ANOVA.
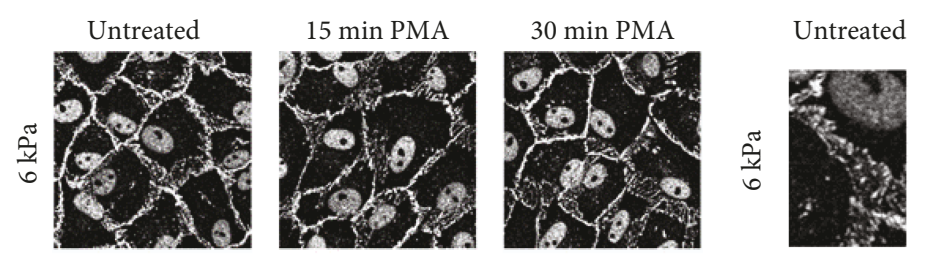

15 min PMA 30 min PMA
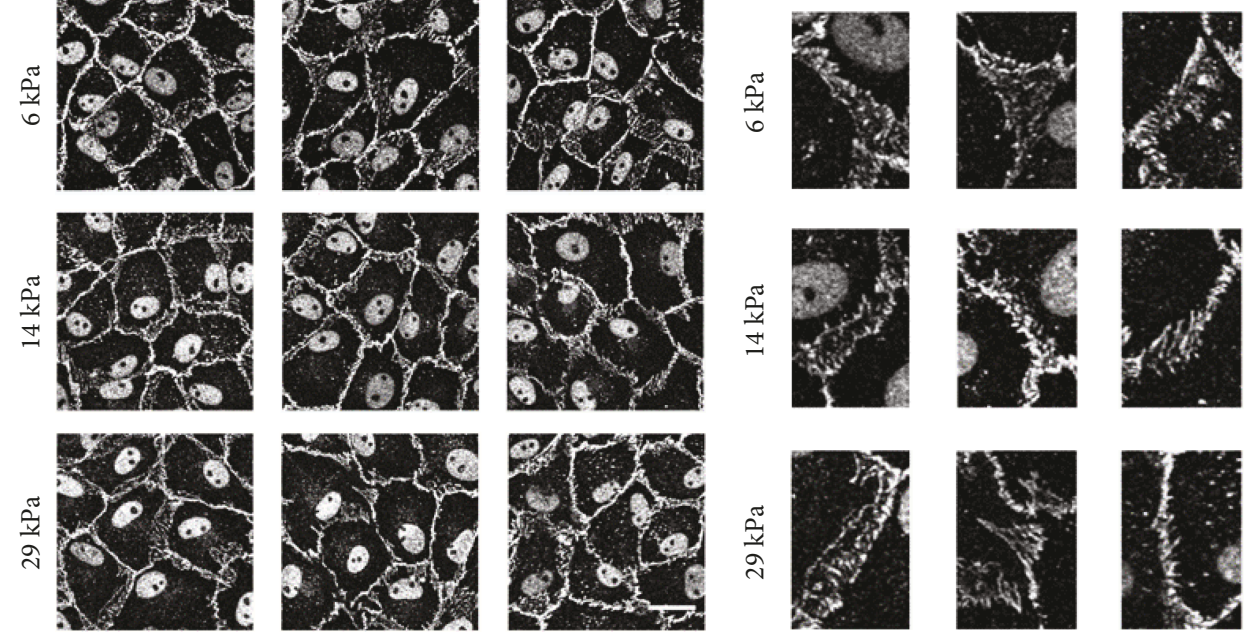

(a)
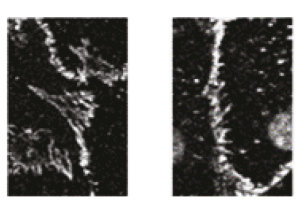

(b)

FIgURE 6: Reticular adherens junction loss was greater in cells on stiffer substrates following PMA. PAEC monolayers on 6, 14, or 29 kPa gels were treated with $1 \mu \mathrm{M}$ PMA for 15 or 30 minutes, prior to fixation and immunofluorescent labeling of the cell-cell junction protein $\beta$-catenin. (a) Maximum intensity projection from confocal $z$-stacks at $60 \mathrm{x}$ magnification. Scale bar is $25 \mu \mathrm{m}$. (b) Representative junctions.

adherens junction loss in response to PMA. In untreated cells on 6,14, and $29 \mathrm{kPa}$ gels, wide reticular adherens junctions were evident between adjacent cells (Figure 6(a), representative magnified junctions in Figure 6(b)). In contrast to what has been observed in other published work, we did not observe any changes in adherens junction based 


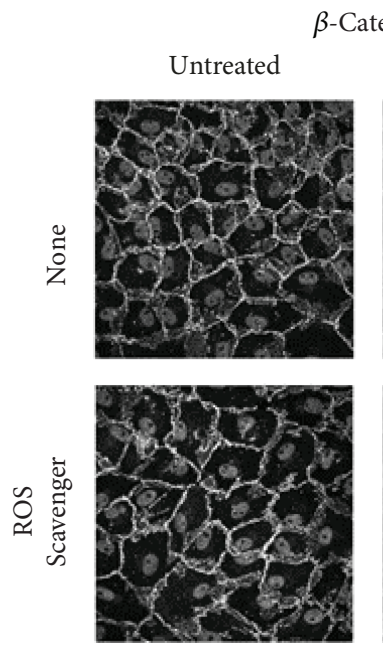

(a)

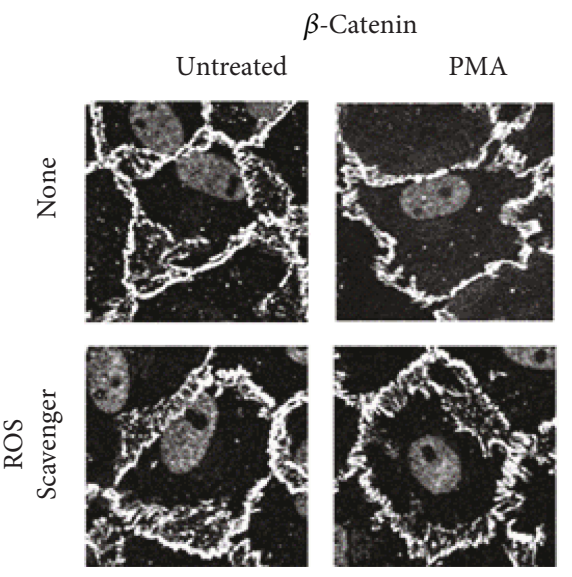

(c)
PMA
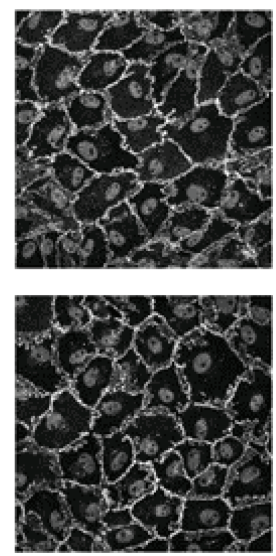
cell-cell membranes and increased peripheral actin fiber formation in response to PMA. Since PMA-induced PKC activation was not affected by substrate stiffness, it is likely that substrate stiffness affected cells through alternative pathways. These data suggest that oxidative stress and its detrimental downstream effects on endothelial cells and vascular disease may be enhanced in stiffer arteries.

The vascular mechanics of the elastin haploinsufficient mouse have been extensively studied, both in terms of passive mechanical stretch in response to increasing pressure and in terms of vasodilation and constriction in response to biochemical stimuli $[13,37,46,47]$. These studies focused primarily on the decrease in total elastin in the vascular wall, as well as the increase in elastin lamellae. We and others did not find any changes in other extracellular matrix proteins, in particular collagen, which is the other primary protein thought to define vascular wall stiffness. However, some recent studies in other tissues in elastin haploinsufficient mice suggest that there are also collagen changes in these animals. The lungs of Eln +/- mice contained nearly twice as much collagen 1 and lysyl oxidase, an important collagen crosslinker, as WT mice [48]. Achilles tendons of Eln+/- mice had the same total collagen content as WT mice but different collagen fibril diameter distribution [49]. Thus, it is possible that the increased stiffness we measured in the Eln $+/$ - aorta relates to changes in collagen content and/or structure.

The thoracic aorta was consistently stiffer than the abdominal aorta in both WT and Eln+/- mice. These data agree with human studies in which aortic stiffness decreased with distance from the heart, especially in older patients $[50,51]$. Other studies in C57BL/6 mice demonstrated that the aortic elastic modulus was highest in the distal thoracic aorta and lowest in the abdominal aorta [52]. In a subsequent study, it was shown that the decrease in aortic stiffness along the length of the aorta was accounted for by a decrease in total and lamellar elastin [53]. Since our data show a proportionally similar decrease in aortic stiffness from the thoracic to the abdominal sections in both WT and Eln+/- mice, it is likely that elastin content is important to the regional stiffness variation.

Our data support other recently published studies showing that substrate stiffness affects not only single endothelial cells but also confluent endothelial monolayers [12]. In vitro studies of cell response to substrate stiffness began when Pelham and Wang first used protein-coated PA gels to show that both rat kidney epithelial and 3T3 fibroblasts spread to a greater extent on stiff than soft substrates [54]. Since that seminal paper, many cell types were shown to change their morphology [55-58], motility [59, 60], differentiation $[61,62]$, and proliferation $[63,64]$ in response to substrate stiffness. For endothelial cells specifically, single cells increase the spread area [65, 66], stiffness [67], cell-matrix and cellcell forces [66, 68], and proliferation [69] with substrate stiffness. However, as cells proliferated and reached confluency, substrate-dependent differences were diminished or no longer observed [70, 71]. Similarly, we did not observe any changes in endothelial cell and actin stress fiber morphology, focal adhesion size, or focal adhesion number in endothelial cell monolayers on substrates of different stiffness. However, while these morphological responses to substrate stiffness are no longer observed as endothelial cells reach confluency, this study shows that both endothelial biochemical responses and cell-cell interactions do change with substrate stiffness.

ROS, specifically superoxide and its byproduct hydrogen peroxide, have been shown to regulate actin fibers in vascular cells $[40,72-74]$. Actin fiber formation in subconfluent reoxygenated hypoxic aortic endothelial cells was inhibited by superoxide dismutase overexpression, suggesting a key role for superoxide [75]. Superoxide can reversibly oxidize proteins, including actin itself. In endothelial cells, actin oxidation may be essential for actin polymerization during cell migration. For example, in migrating mouse aortic endothelial cells, actin monomer incorporation into actin fibers was diminished following treatment with the NADPH oxidase inhibitor diphenyleneiodonium (DPI) and a superoxide dismutase mimetic [76]. Alternatively, superoxide can oxidize RhoA, enhancing GDP dissociation and subsequent activation. Fibroblasts with an oxidation-resistant form of RhoA did not form stress fibers in response to hydrogen peroxide [77]. While the source of increased ROS in endothelial cells on stiffer substrates remains unknown, we hypothesize that stiff substrates increase NADPH oxidase production or assembly, since NADPH oxidase appears to produce the most nonmitochondrial superoxide in endothelial cells [78]. We hope to investigate this mechanism further in future studies.

Although endothelial oxidative stress has not been studied on varied stiffness substrates, endothelial superoxide production is mechanosensitive, specifically in response to shear stress [79]. Bovine aortic endothelial cells produced three times more superoxide under oscillatory shear stress compared to laminar flow [80]. Shear stress activates Rac, which is downstream of integrin activation and contributes to ROS production $[81,82]$. Epithelial cells have been shown to produce more ROS when on stiffer substrates. MMP-3stimulated ROS production was approximately 3.5 -fold higher in epithelial cells on $4.02 \mathrm{kPa}$ substrates compared to $0.13 \mathrm{kPa}$ substrates; $\beta 1$ integrin subunit knockdown eliminated ROSproductioninresponsetoMMP-3[83].These findings suggest that integrin activation-induced Racl activity contributes to ROS production in cells on stiffer substrates [84].

The increase in adherens junction disruption could be either contractility-dependent or contractility-independent. Permeability agents, including thrombin, lipopolysaccharide (LPS), TNF- $\alpha$, and vascular endothelial growth factor (VEGF), activate the Rho/ROCK pathway and cell contractility [85]. The ROCK inhibitor Y-27632 prevented adherens junction disruption in endothelial monolayer studies, although some effects may be endothelial subtype-dependent (e.g., macrovascular or microvascular) $[86,87]$. In epithelial cell protrusions, $\mathrm{H}_{2} \mathrm{O}_{2}$ increased actin polymerization, cofilin activity, and barbed ends; however, myosin IIA did not colocalize with actin fibers in $\mathrm{H}_{2} \mathrm{O}_{2}$-treated cell protrusions [88]. These data fit with our results that actin contractility did not increase with oxidative stress. Therefore, it is more likely in our case that oxidative stress induced contractility-independent adherens junction 
disruption. ROS also disrupt cell-cell junctions through VE-cadherin phosphorylation. Endothelial cell treatment with permeability agonists, such as VEGF and histamine, resulted in VE-cadherin tyrosine phosphorylation $[89,90]$. In HUVECs, the ROS scavenger $\mathrm{N}$-acetyl cysteine prevented VE-cadherin phosphorylation by TNF- $\alpha$ [91]. Thus, we hypothesize that adherens junction protein phosphorylation resulted in cell-cell junction loss, although we did not directly measure it.

ROS can also lead to adverse effects on the endothelium beyond adherens junction loss. For example, superoxide $\left(\mathrm{O}_{2}{ }^{-}\right)$interacts with nitric oxide (NO) to form peroxynitrite. This interaction effectively decreases the NO availability, which is needed for vasodilation [92, 93]. Superoxide also uncouples eNOS by oxidizing the eNOS cofactor tetrahydrobiopterin $\left(\mathrm{BH}_{4}\right)$ [94-96]. Uncoupled eNOS produces more superoxide instead of NO [97], which further increases peroxynitrite. Protein nitration by peroxynitrite is widely observed in many cardiovascular diseases [98]. Thus, vascular stiffness-induced endothelial oxidative stress could have damaging effects beyond endothelial barrier function.

Substrate stiffness also affects other cell types beyond endothelial cells, including fibroblasts, breast cancer cells, and stem cells $[99,100]$. In vivo, tumors are stiffer than their surrounding environment, which may alter both basal function and inflammatory response in all of these cell types. In addition, some tumors overexpress specific NADPH oxidases [101]. This overexpression could couple with increased tumor stiffness to further magnify oxidative stress in tumors. Tumor oxidative stress contributes to tissue injury and DNA damage in premalignant conditions, as well as in cancer initiation and progression. Since the tumor cells themselves may be resistant to oxidative stress, the injury to the surrounding tissue may be more severe [102]. Thus, stiffness-associated ROS inhibition could potentially decrease cancer-induced damage and inhibit cancer metastasis through compromised blood vessels.

While our work shows that PMA-induced oxidative stress increases with substrate stiffness, our research is not without limitations. Phorbol esters, including PMA, are found in certain plants and can cause toxicity in animals when consumed [38]. Yet, PMA itself is not involved in cardiovascular disease pathogenesis. We chose to use PMA to isolate ROS production from cell contractility in cell-cell junction loss [25, 26]; however, these studies should be repeated using a physiologically relevant ROS inducer (e.g., tumor necrosis factor- $\alpha$ ). PA gels do not fully capture the endothelial mechanical environment, including substrate viscoelasticity and relaxation as well as shear stress or strain. Several recent papers have shown interactions between shear stress and substrate stiffness, demonstrating that softer substrates augmented the atheroprotective effects of laminar shear stress $[103,104]$. We also were not able to specifically detect superoxide in intact vessels under physiological conditions due to technical challenges. In future studies, a superoxide-specific indicator such as dihydroethidium could be used along with NADPH oxidase component knockdown to support the hypothesis that stiffness-induced integrin activation enhances superoxide production by NADPH oxidase [105].

\section{Conclusions}

This work illustrates a novel potential mechanism for substrate-enhanced oxidative stress in response to PKC activation in the endothelium. Since many endothelial cell studies are performed on tissue culture polystyrene of essentially infinite stiffness, these studies may overestimate endothelial cell response to stressors. Further study of the interaction between arterial stiffness and oxidative stress could improve therapies to prevent or ameliorate endothelial barrier dysfunction.

\section{Data Availability}

AFM indentation curves, PKC quantification, and immunofluorescence images used to support the finding of this study may be released upon application to the corresponding author.

\section{Conflicts of Interest}

The authors declare that there is no conflict of interest regarding the publication of this paper.

\section{Authors' Contributions}

RLU helped design the study, carried out all experiments, helped analyze the data, and drafted the manuscript. SS assisted with data analysis. AMC helped design the study, analyzed the data, and drafted the manuscript. All authors gave final approval for publication.

\section{Acknowledgments}

This work was supported by the American Heart Association (grant number SDG4460068). We thank Patrick Osei-Owusu for providing the WT and Eln+/- mouse aortae.

\section{References}

[1] S. Laurent, J. Cockcroft, L. van Bortel et al., "Expert consensus document on arterial stiffness: methodological issues and clinical applications," European Heart Journal, vol. 27, no. 21, pp. 2588-2605, 2006.

[2] C. Vlachopoulos, K. Aznaouridis, and C. Stefanadis, "Prediction of cardiovascular events and all-cause mortality with arterial stiffness: a systematic review and meta-analysis," Journal of the American College of Cardiology, vol. 55, no. 13, pp. 1318-1327, 2010.

[3] Y. Ben-Shlomo, M. Spears, C. Boustred et al., "Aortic pulse wave velocity improves cardiovascular event prediction: an individual participant meta-analysis of prospective observational data from 17,635 subjects," Journal of the American College of Cardiology, vol. 63, no. 7, pp. 636-646, 2014.

[4] A. J. Bank, H. Wang, J. E. Holte, K. Mullen, R. Shammas, and S. H. Kubo, "Contribution of collagen, elastin, and smooth muscle to in vivo human brachial artery wall stress and elastic modulus," Circulation, vol. 94, no. 12, pp. 3263-3270, 1996.

[5] B. S. Fleenor, "Large elastic artery stiffness with aging: novel translational mechanisms and interventions," Aging and Disease, vol. 4, no. 2, pp. 76-83, 2013. 
[6] M. Veerasamy, G. A. Ford, D. Neely et al., "Association of aging, arterial stiffness, and cardiovascular disease: a review," Cardiology in Review, vol. 22, no. 5, pp. 223-232, 2014.

[7] C. Xu, C. K. Zarins, P. S. Pannaraj, H. S. Bassiouny, and S. Glagov, "Hypercholesterolemia superimposed by experimental hypertension induces differential distribution of collagen and elastin," Arteriosclerosis, Thrombosis, and Vascular Biology, vol. 20, no. 12, pp. 2566-2572, 2000.

[8] M. Cecelja and P. Chowienczyk, "Dissociation of aortic pulse wave velocity with risk factors for cardiovascular disease other than hypertension: a systematic review," Hypertension, vol. 54, no. 6, pp. 1328-1336, 2009.

[9] A. Scuteri, P. G. Cunha, E. A. Rosei et al., "Arterial stiffness and influences of the metabolic syndrome: a cross-countries study," Atherosclerosis, vol. 233, no. 2, pp. 654-660, 2014.

[10] G. F. Mitchell, “Arterial stiffness: insights from Framingham and Iceland," Current Opinion in Nephrology and Hypertension, vol. 24, no. 1, pp. 1-7, 2015.

[11] B. M. Kaess, J. Rong, M. G. Larson et al., "Aortic stiffness, blood pressure progression, and incident hypertension," Journal of the American Medical Association, vol. 308, no. 9, pp. 875-881, 2012.

[12] J. Huynh, N. Nishimura, K. Rana et al., "Age-related intimal stiffening enhances endothelial permeability and leukocyte transmigration," Science Translational Medicine, vol. 3, no. 112, article 112ra122, 2011.

[13] P. Osei-Owusu, R. H. Knutsen, B. A. Kozel, H. H. Dietrich, K. J. Blumer, and R. P. Mecham, "Altered reactivity of resistance vasculature contributes to hypertension in elastin insufficiency," American Journal of Physiology-Heart and Circulatory Physiology, vol. 306, no. 5, pp. H654-H666, 2014.

[14] A. A. Birukova, X. Tian, I. Cokic, Y. Beckham, M. L. Gardel, and K. G. Birukov, "Endothelial barrier disruption and recovery is controlled by substrate stiffness," Microvascular Research, vol. 87, pp. 50-57, 2013.

[15] R. Krishnan, D. D. Klumpers, C. Y. Park et al., "Substrate stiffening promotes endothelial monolayer disruption through enhanced physical forces," American Journal of Physiology-Cell Physiology, vol. 300, no. 1, pp. C146-C154, 2011.

[16] G. Faury, M. Pezet, R. H. Knutsen et al., "Developmental adaptation of the mouse cardiovascular system to elastin haploinsufficiency," Journal of Clinical Investigation, vol. 112, no. 9, pp. 1419-1428, 2003.

[17] C. M. McEniery, S. Wallace, I. S. Mackenzie et al., "Endothelial function is associated with pulse pressure, pulse wave velocity, and augmentation index in healthy humans," Hypertension, vol. 48, no. 4, pp. 602-608, 2006.

[18] A. Nigam, G. F. Mitchell, J. Lambert, and J. C. Tardif, "Relation between conduit vessel stiffness (assessed by tonometry) and endothelial function (assessed by flow-mediated dilatation) in patients with and without coronary heart disease," The American Journal of Cardiology, vol. 92, no. 4, pp. 395399, 2003.

[19] A. M. Briones and R. M. Touyz, "Oxidative stress and hypertension: current concepts," Current Hypertension Reports, vol. 12, no. 2, pp. 135-142, 2010.

[20] P. D. Ray, B.-W. Huang, and Y. Tsuji, "Reactive oxygen species (ROS) homeostasis and redox regulation in cellular signaling," Cellular Signalling, vol. 24, no. 5, pp. 981-990, 2012.
[21] F. Cosentino, M. Eto, P. de Paolis et al., "High glucose causes upregulation of cyclooxygenase-2 and alters prostanoid profile in human endothelial cells: role of protein kinase $\mathrm{C}$ and reactive oxygen species," Circulation, vol. 107, no. 7, pp. 1017-1023, 2003.

[22] T. Inoguchi, P. Li, F. Umeda et al., "High glucose level and free fatty acid stimulate reactive oxygen species production through protein kinase $\mathrm{C}$-dependent activation of $\mathrm{NAD}(\mathrm{P}) \mathrm{H}$ oxidase in cultured vascular cells," Diabetes, vol. 49 , no. 11, pp. 1939-1945, 2000.

[23] L. Quagliaro, L. Piconi, R. Assaloni, L. Martinelli, E. Motz, and A. Ceriello, "Intermittent high glucose enhances apoptosis related to oxidative stress in human umbilical vein endothelial cells: the role of protein kinase $\mathrm{C}$ and $\mathrm{NAD}(\mathrm{P}) \mathrm{H}$ oxidase activation," Diabetes, vol. 52, no. 11, pp. 2795-2804, 2003.

[24] M. T. Elnakish, H. H. Hassanain, P. M. Janssen, M. G. Angelos, and M. Khan, "Emerging role of oxidative stress in metabolic syndrome and cardiovascular diseases: important role of Rac/NADPH oxidase," The Journal of Pathology, vol. 231, no. 3, pp. 290-300, 2013.

[25] J. G. N. Garcia, H. W. Davis, and C. E. Patterson, "Regulation of endothelial cell gap formation and barrier dysfunction: role of myosin light chain phosphorylation," Journal of Cellular Physiology, vol. 163, no. 3, pp. 510-522, 1995.

[26] N. V. Bogatcheva, A. D. Verin, P. Wang et al., "Phorbol esters increase MLC phosphorylation and actin remodeling in bovine lung endothelium without increased contraction," American Journal of Physiology-Lung Cellular and Molecular Physiology, vol. 285, no. 2, pp. L415-L426, 2003.

[27] A. B. Moy, K. Blackwell, N. Wang et al., "Phorbol ester-mediated pulmonary artery endothelial barrier dysfunction through regulation of actin cytoskeletal mechanics," American Journal of Physiology-Lung Cellular and Molecular Physiology, vol. 287, no. 1, pp. L153-L167, 2004.

[28] J. E. Stasek, C. E. Patterson, and J. G. N. Garcia, "Proteinkinase-c phosphorylates caldesmon77 and vimentin and enhances albumin permeability across cultured bovine pulmonary-artery endothelial-cell monolayers," Journal of Cellular Physiology, vol. 153, no. 1, pp. 62-75, 1992.

[29] N. V. Bogatcheva, A. Birukova, T. Borbiev et al., "Caldesmon is a cytoskeletal target for PKC in endothelium," Journal of Cellular Biochemistry, vol. 99, no. 6, pp. 1593-1605, 2006.

[30] A. J. Oliveira-dos-Santos, G. Matsumoto, B. E. Snow et al., "Regulation of T cell activation, anxiety, and male aggression by RGS2," Proceedings of the National Academy of Sciences of the United States of America, vol. 97, no. 22, pp. 1227212277, 2000.

[31] J. Peloquin, J. Huynh, R. M. Williams, and C. A. ReinhartKing, "Indentation measurements of the subendothelial matrix in bovine carotid arteries," Journal of Biomechanics, vol. 44, no. 5, pp. 815-821, 2011.

[32] J. Solon, I. Levental, K. Sengupta, P. C. Georges, and P. A. Janmey, "Fibroblast adaptation and stiffness matching to soft elastic substrates," Biophysical Journal, vol. 93, no. 12, pp. 4453-4461, 2007.

[33] J. R. Tse and A. J. Engler, "Preparation of hydrogel substrates with tunable mechanical properties," Current Protocols in Cell Biology, vol. 47, no. 1, pp. 10.16.1-10.16.16, 2010.

[34] R. L. Urbano, C. Furia, S. Basehore, and A. M. Clyne, "Stiff substrates increase inflammation-induced endothelial 
monolayer tension and permeability," Biophysical Journal, vol. 113, no. 3, pp. 645-655, 2017.

[35] N. Otsu, "A threshold selection method from gray-level histograms," IEEE Transactions on Systems, Man, and Cybernetics, vol. 9, no. 1, pp. 62-66, 1979.

[36] J. E. Wagenseil, C. H. Ciliberto, R. H. Knutsen, M. A. Levy, A. Kovacs, and R. P. Mecham, "Reduced vessel elasticity alters cardiovascular structure and function in newborn mice," Circulation Research, vol. 104, no. 10, pp. 1217-1224, 2009.

[37] L. Carta, J. E. Wagenseil, R. H. Knutsen et al., "Discrete contributions of elastic fiber components to arterial development and mechanical compliance," Arteriosclerosis, Thrombosis, and Vascular Biology, vol. 29, no. 12, pp. 2083-2089, 2009.

[38] G. Goel, H. P. S. Makkar, G. Francis, and K. Becker, "Phorbol esters: structure, biological activity, and toxicity in animals," International Journal of Toxicology, vol. 26, no. 4, pp. 279288, 2007.

[39] J. M. Li, A. M. Mullen, S. Yun et al., "Essential role of the NADPH oxidase subunit $\mathrm{p} 47^{\text {phox }}$ in endothelial cell superoxide production in response to phorbol ester and tumor necrosis factor- $\alpha$, Circulation Research, vol. 90, no. 2, pp. 143-150, 2002.

[40] H. Lum and K. A. Roebuck, "Oxidant stress and endothelial cell dysfunction," American Journal of Physiology-Cell Physiology, vol. 280, no. 4, pp. C719-C741, 2001.

[41] S. van Wetering, J. D. van Buul, S. Quik et al., "Reactive oxygen species mediate Rac-induced loss of cell-cell adhesion in primary human endothelial cells," Journal of Cell Science, vol. 115, no. 9, pp. 1837-1846, 2002.

[42] P. V. Usatyuk and V. Natarajan, "Regulation of reactive oxygen species-induced endothelial cell-cell and cell-matrix contacts by focal adhesion kinase and adherens junction proteins," American Journal of Physiology-Lung Cellular and Molecular Physiology, vol. 289, no. 6, pp. L999-L1010, 2005.

[43] C. G. Kevil, N. Ohno, D. C. Gute et al., "Role of cadherin internalization in hydrogen peroxide-mediated endothelial permeability," Free Radical Biology and Medicine, vol. 24, no. 6, pp. 1015-1022, 1998.

[44] G. R. Drummond, S. Selemidis, K. K. Griendling, and C. G. Sobey, "Combating oxidative stress in vascular disease: NADPH oxidases as therapeutic targets," Nature Reviews Drug Discovery, vol. 10, no. 6, pp. 453-471, 2011.

[45] N. R. Madamanchi, A. Vendrov, and M. S. Runge, "Oxidative stress and vascular disease," Arteriosclerosis Thrombosis and Vascular Biology, vol. 25, no. 1, pp. 29-38, 2005.

[46] J. E. Wagenseil, N. L. Nerurkar, R. H. Knutsen, R. J. Okamoto, D. Y. Li, and R. P. Mecham, "Effects of elastin haploinsufficiency on the mechanical behavior of mouse arteries," American Journal of Physiology-Heart and Circulatory Physiology, vol. 289, no. 3, pp. H1209-H1217, 2005.

[47] B. A. Sather, D. Hageman, and J. E. Wagenseil, "Murray's law in elastin haploinsufficient (Eln+/-) and wild-type (WT) mice," Journal of Biomechanical Engineering, vol. 134, no. 12, p. 124504, 2012.

[48] A. Hilgendorff, K. Parai, R. Ertsey et al., "Lung matrix and vascular remodeling in mechanically ventilated elastin haploinsufficient newborn mice," American Journal of Physiology-Lung Cellular and Molecular Physiology, vol. 308, no. 5, pp. L464-L478, 2015.
[49] J. D. Eekhoff, F. Fang, L. G. Kahan et al., "Functionally distinct tendons from elastin haploinsufficient mice exhibit mild stiffening and tendon-specific structural alteration," Journal of Biomechanical Engineering, vol. 139, no. 11, p. 111003, 2017.

[50] V. Taviani, S. S. Hickson, C. J. Hardy et al., "Age-related changes of regional pulse wave velocity in the descending aorta using Fourier velocity encoded M-mode," Magnetic Resonance in Medicine, vol. 65, no. 1, pp. 261-268, 2011.

[51] W. J. Rogers, Y. L. Hu, D. Coast et al., "Age-associated changes in regional aortic pulse wave velocity," Journal of the American College of Cardiology, vol. 38, no. 4, pp. 1123$1129,2001$.

[52] X. Guo and G. S. Kassab, "Variation of mechanical properties along the length of the aorta in C57bl/6 mice," American Journal of Physiology-Heart and Circulatory Physiology, vol. 285, no. 6, pp. H2614-H2622, 2003.

[53] T. E. Clark, M. A. Lillie, A. W. Vogl, J. M. Gosline, and R. E. Shadwick, "Mechanical contribution of lamellar and interlamellar elastin along the mouse aorta," Journal of Biomechanics, vol. 48, no. 13, pp. 3599-3605, 2015.

[54] R. J. Pelham and Y.-L. Wang, "Cell locomotion and focal adhesions are regulated by substrate flexibility," Proceedings of the National Academy of Sciences of the United States of America, vol. 94, no. 25, pp. 13661-13665, 1997.

[55] J. P. Califano and C. A. Reinhart-King, "A balance of substrate mechanics and matrix chemistry regulates endothelial cell network assembly," Cellular and Molecular Bioengineering, vol. 1, no. 2-3, pp. 122-132, 2008.

[56] A. Engler, L. Bacakova, C. Newman, A. Hategan, M. Griffin, and D. Discher, "Substrate compliance versus ligand density in cell on gel responses," Biophysical Journal, vol. 86, no. 1, pp. 617-628, 2004.

[57] A. J. Engler, C. Carag-Krieger, C. P. Johnson et al., "Embryonic cardiomyocytes beat best on a matrix with heart-like elasticity: scar-like rigidity inhibits beating," Journal of Cell Science, vol. 121, no. 22, pp. 3794-3802, 2008.

[58] P. Moshayedi, L. da F Costa, A. Christ et al., "Mechanosensitivity of astrocytes on optimized polyacrylamide gels analyzed by quantitative morphometry," Journal of Physics: Condensed Matter, vol. 22, no. 19, p. 194114, 2010.

[59] P. W. Oakes, D. C. Patel, N. A. Morin et al., "Neutrophil morphology and migration are affected by substrate elasticity," Blood, vol. 114, no. 7, pp. 1387-1395, 2009.

[60] S. R. Peyton and A. J. Putnam, "Extracellular matrix rigidity governs smooth muscle cell motility in a biphasic fashion," Journal of Cellular Physiology, vol. 204, no. 1, pp. 198-209, 2005.

[61] A. J. Engler, M. A. Griffin, S. Sen, C. G. Bönnemann, H. L. Sweeney, and D. E. Discher, "Myotubes differentiate optimally on substrates with tissue-like stiffness," The Journal of Cell Biology, vol. 166, no. 6, pp. 877-887, 2004.

[62] A. J. Engler, S. Sen, H. L. Sweeney, and D. E. Discher, "Matrix elasticity directs stem cell lineage specification," Cell, vol. 126, no. 4, pp. 677-689, 2006.

[63] T. A. Ulrich, E. M. de Juan Pardo, and S. Kumar, "The mechanical rigidity of the extracellular matrix regulates the structure, motility, and proliferation of glioma cells," Cancer Research, vol. 69, no. 10, pp. 4167-4174, 2009.

[64] S. R. Peyton, C. B. Raub, V. P. Keschrumrus, and A. J. Putnam, "The use of poly(ethylene glycol) hydrogels to 
investigate the impact of ECM chemistry and mechanics on smooth muscle cells," Biomaterials, vol. 27, no. 28, pp. 4881-4893, 2006.

[65] J. A. Wood, N. M. Shah, C. T. McKee et al., "The role of substratum compliance of hydrogels on vascular endothelial cell behavior," Biomaterials, vol. 32, no. 22, pp. 5056-5064, 2011.

[66] J. P. Califano and C. A. Reinhart-King, "Substrate stiffness and cell area predict cellular traction stresses in single cells and cells in contact," Cellular and Molecular Bioengineering, vol. 3, no. 1, pp. 68-75, 2010.

[67] F. J. Byfield, R. K. Reen, T. P. Shentu, I. Levitan, and K. J. Gooch, "Endothelial actin and cell stiffness is modulated by substrate stiffness in 2D and 3D," Journal of Biomechanics, vol. 42, no. 8, pp. 1114-1119, 2009.

[68] V. Maruthamuthu, B. Sabass, U. S. Schwarz, and M. L. Gardel, "Cell-ECM traction force modulates endogenous tension at cell-cell contacts," Proceedings of the National Academy of Sciences of the United States of America, vol. 108, no. 12, pp. 4708-4713, 2011.

[69] Y. T. Yeh, S. S. Hur, J. Chang et al., "Matrix stiffness regulates endothelial cell proliferation through septin 9," PLoS One, vol. 7, no. 10, 2012.

[70] T. Yeung, P. C. Georges, L. A. Flanagan et al., "Effects of substrate stiffness on cell morphology, cytoskeletal structure, and adhesion," Cell Motility and the Cytoskeleton, vol. 60, no. 1, pp. 24-34, 2005.

[71] K. M. Stroka and H. Aranda-Espinoza, "Endothelial cell substrate stiffness influences neutrophil transmigration via myosin light chain kinase-dependent cell contraction," Blood, vol. 118, no. 6, pp. 1632-1640, 2011.

[72] I. Dalle-Donne, R. Rossi, A. Milzani, P. di Simplicio, and R. Colombo, "The actin cytoskeleton response to oxidants: from small heat shock protein phosphorylation to changes in the redox state of actin itself," Free Radical Biology and Medicine, vol. 31, no. 12, pp. 1624-1632, 2001.

[73] Q. Xu, L. P. Huff, M. Fujii, and K. K. Griendling, "Redox regulation of the actin cytoskeleton and its role in the vascular system," Free Radical Biology and Medicine, vol. 109, pp. 84-107, 2017.

[74] K. Buyukhatipoglu and A. M. Clyne, "Superparamagnetic iron oxide nanoparticles change endothelial cell morphology and mechanics via reactive oxygen species formation," Journal of Biomedical Materials Research Part A, vol. 96A, no. 1, pp. 186-195, 2011.

[75] L. E. Crawford, E. E. Milliken, K. Irani et al., "Superoxide mediated actin response in post-hypoxic endothelial cells," Journal of Biological Chemistry, vol. 271, no. 43, pp. 2686326867, 1996.

[76] L. Moldovan, N. I. Moldovan, R. H. Sohn, S. A. Parikh, and P. J. Goldschmidt-Clermont, "Redox changes of cultured endothelial cells and actin dynamics," Circulation Research, vol. 86, no. 5, pp. 549-557, 2000.

[77] A. Aghajanian, E. S. Wittchen, S. L. Campbell, and K. Burridge, "Direct activation of RhoA by reactive oxygen species requires a redox-sensitive motif," PLoS One, vol. 4, no. 11, article e8045, 2009.

[78] K. M. Mohazzab, P. M. Kaminski, and M. S. Wolin, "NADH oxidoreductase is a major source of superoxide anion in bovine coronary artery endothelium," American Journal of Physiology-Heart and Circulatory Physiology, vol. 266, no. 6, pp. H2568-H2572, 1994.
[79] R. P. Brandes, N. Weissmann, and K. Schröder, "Nox family NADPH oxidases in mechano-transduction: mechanisms and consequences," Antioxidants \& Redox Signaling, vol. 20, no. 6, pp. 887-898, 2014.

[80] J. S. McNally, M. E. Davis, D. P. Giddens et al., "Role of xanthine oxidoreductase and $\mathrm{NAD}(\mathrm{P}) \mathrm{H}$ oxidase in endothelial superoxide production in response to oscillatory shear stress," American Journal of Physiology-Heart and Circulatory Physiology, vol. 285, no. 6, pp. H2290-H2297, 2003.

[81] E. Tzima, M. del Pozo, W. B. Kiosses et al., "Activation of Rac1 by shear stress in endothelial cells mediates both cytoskeletal reorganization and effects on gene expression," The EMBO Journal, vol. 21, no. 24, pp. 6791-6800, 2002.

[82] L. H. Yeh, Y. J. Park, R. J. Hansalia et al., "Shear-induced tyrosine phosphorylation in endothelial cells requires Rac1dependent production of ROS," American Journal of Physiology-Cell Physiology, vol. 276, no. 4, pp. C838-C847, 1999.

[83] K. Lee, Q. K. Chen, C. Lui, M. A. Cichon, D. C. Radisky, and C. M. Nelson, "Matrix compliance regulates Raclb localization, NADPH oxidase assembly, and epithelialmesenchymal transition," Molecular Biology of the Cell, vol. 23, no. 20, pp. 4097-4108, 2012.

[84] M. A. del Pozo, N. B. Alderson, W. B. Kiosses, H. H. Chiang, R. G. Anderson, and M. A. Schwartz, "Integrins regulate Rac targeting by internalization of membrane domains," Science, vol. 303, no. 5659, pp. 839-842, 2004.

[85] B. Wojciak-Stothard and A. J. Ridley, "Rho GTPases and the regulation of endothelial permeability," Vascular Pharmacology, vol. 39, no. 4-5, pp. 187-199, 2002.

[86] J. M. Carbajal, M. L. Gratrix, C. H. Yu, and R. C. Schaeffer Jr., "ROCK mediates thrombin's endothelial barrier dysfunction," American Journal of Physiology-Cell Physiology, vol. 279, no. 1, pp. C195-C204, 2000.

[87] A. A. Birukova, K. Smurova, K. G. Birukov, K. Kaibuchi, J. G. N. Garcia, and A. D. Verin, "Role of Rho GTPases in thrombin-induced lung vascular endothelial cells barrier dysfunction," Microvascular Research, vol. 67, no. 1, pp. 64-77, 2004.

[88] N. Taulet, V. D. Delorme-Walker, and C. DerMardirossian, "Reactive oxygen species regulate protrusion efficiency by controlling actin dynamics," PLoS One, vol. 7, no. 8, 2012.

[89] S. Esser, M. G. Lampugnani, M. Corada, E. Dejana, and W. Risau, "Vascular endothelial growth factor induces VE-cadherin tyrosine phosphorylation in endothelial cells," Journal of Cell Science, vol. 111, pp. 1853-1865, 1998.

[90] P. Andriopoulou, P. Navarro, A. Zanetti, M. G. Lampugnani, and E. Dejana, "Histamine induces tyrosine phosphorylation of endothelial cell-to-cell adherens junctions," Arteriosclerosis, Thrombosis, and Vascular Biology, vol. 19, no. 10, pp. 2286-2297, 1999.

[91] F. E. Nwariaku, Z. Liu, X. Zhu et al., "NADPH oxidase mediates vascular endothelial cadherin phosphorylation and endothelial dysfunction," Blood, vol. 104, no. 10, pp. 32143220, 2004.

[92] R. E. Huie and S. Padmaja, "The reaction of no with superoxide," Free Radical Research Communications, vol. 18, no. 4, pp. 195-199, 1993.

[93] S. Moncada, R. M. Palmer, and E. A. Higgs, "Nitric-oxide physiology, pathophysiology, and pharmacology," Pharmacological Reviews, vol. 43, no. 2, pp. 109-142, 1991. 
[94] T. Walsh, T. Donnelly, and D. Lyons, "Impaired endothelial nitric oxide bioavailability: a common link between aging, hypertension, and atherogenesis?," Journal of the American Geriatrics Society, vol. 57, no. 1, pp. 140-145, 2009.

[95] U. Landmesser, S. Dikalov, S. R. Price et al., "Oxidation of tetrahydrobiopterin leads to uncoupling of endothelial cell nitric oxide synthase in hypertension," Journal of Clinical Investigation, vol. 111, no. 8, pp. 1201-1209, 2003.

[96] F. Cosentino, J. E. Barker, M. P. Brand et al., "Reactive oxygen species mediate endothelium-dependent relaxations in tetrahydrobiopterin-deficient mice," Arteriosclerosis, Thrombosis, and Vascular Biology, vol. 21, no. 4, pp. 496-502, 2001.

[97] D. Stuehr, S. Pou, and G. M. Rosen, "Oxygen reduction by nitric-oxide synthases," Journal of Biological Chemistry, vol. 276, no. 18, pp. 14533-14536, 2001.

[98] I. V. Turko and F. Murad, "Protein nitration in cardiovascular diseases," Pharmacological Reviews, vol. 54, no. 4, pp. 619634, 2002.

[99] C. A. Reinhart-King, "How matrix properties control the selfassembly and maintenance of tissues," Annals of Biomedical Engineering, vol. 39, no. 7, pp. 1849-1856, 2011.

[100] D. E. Discher, P. Janmey, and Y. L. Wang, "Tissue cells feel and respond to the stiffness of their substrate," Science, vol. 310, no. 5751, pp. 1139-1143, 2005.

[101] K. Roy, Y. Wu, J. L. Meitzler et al., "NADPH oxidases and cancer," Clinical Science, vol. 128, no. 12, pp. 863-875, 2015.

[102] V. Sosa, T. Moliné, R. Somoza, R. Paciucci, H. Kondoh, and M. E. LLeonart, "Oxidative stress and cancer: an overview," Ageing Research Reviews, vol. 12, no. 1, pp. 376-390, 2013.

[103] J. C. Kohn, D. W. Zhou, F. Bordeleau et al., "Cooperative effects of matrix stiffness and fluid shear stress on endothelial cell behavior," Biophysical Journal, vol. 108, no. 3, pp. 471478, 2015.

[104] P. A. Galie, A. van Oosten, C. S. Chen, and P. A. Janmey, "Application of multiple levels of fluid shear stress to endothelial cells plated on polyacrylamide gels," Lab on a Chip, vol. 15, no. 4, pp. 1205-1212, 2015.

[105] W. O. Carter, P. K. Narayanan, and J. P. Robinson, "Intracellular hydrogen peroxide and superoxide anion detection in endothelial cells," Journal of Leukocyte Biology, vol. 55, no. 2, pp. 253-258, 1994. 


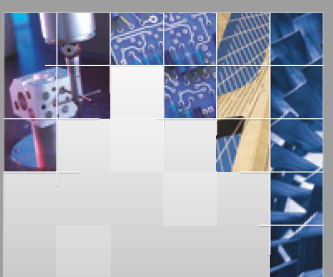

\section{Enfincering}
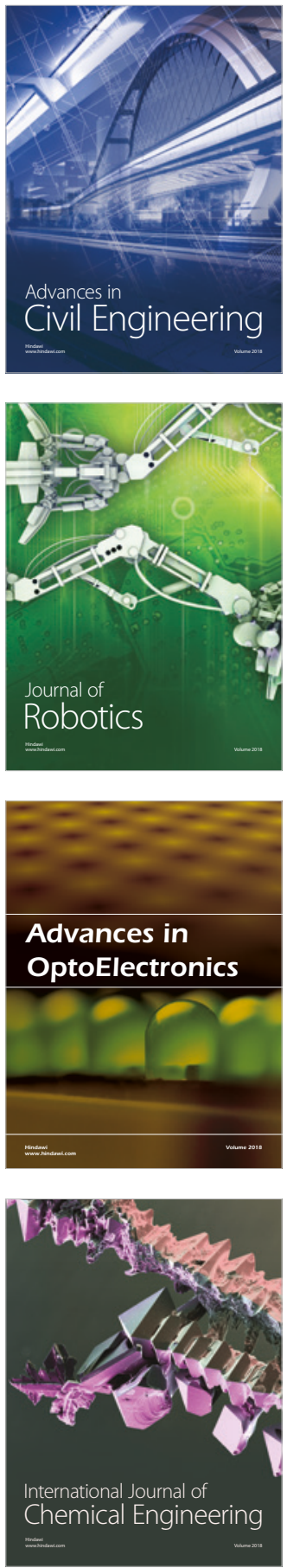

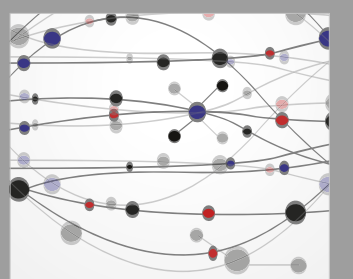

\section{Rotating \\ Machinery}

The Scientific World Journal

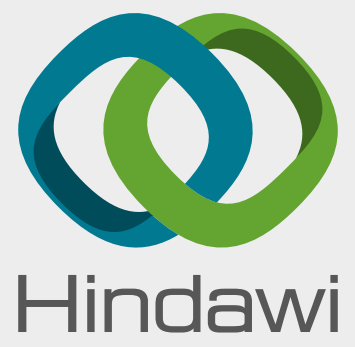

Submit your manuscripts at

www.hindawi.com
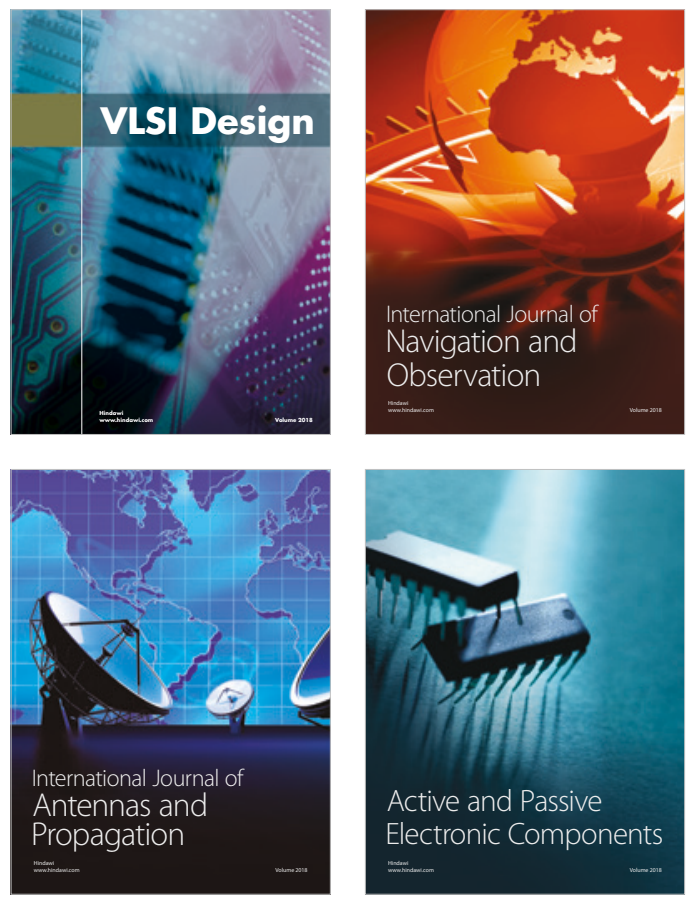
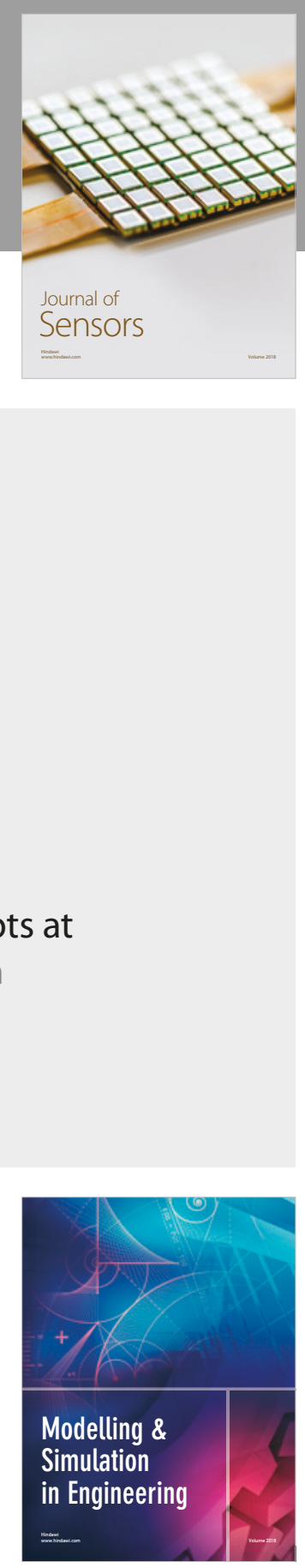

\section{Advances \\ Multimedia}
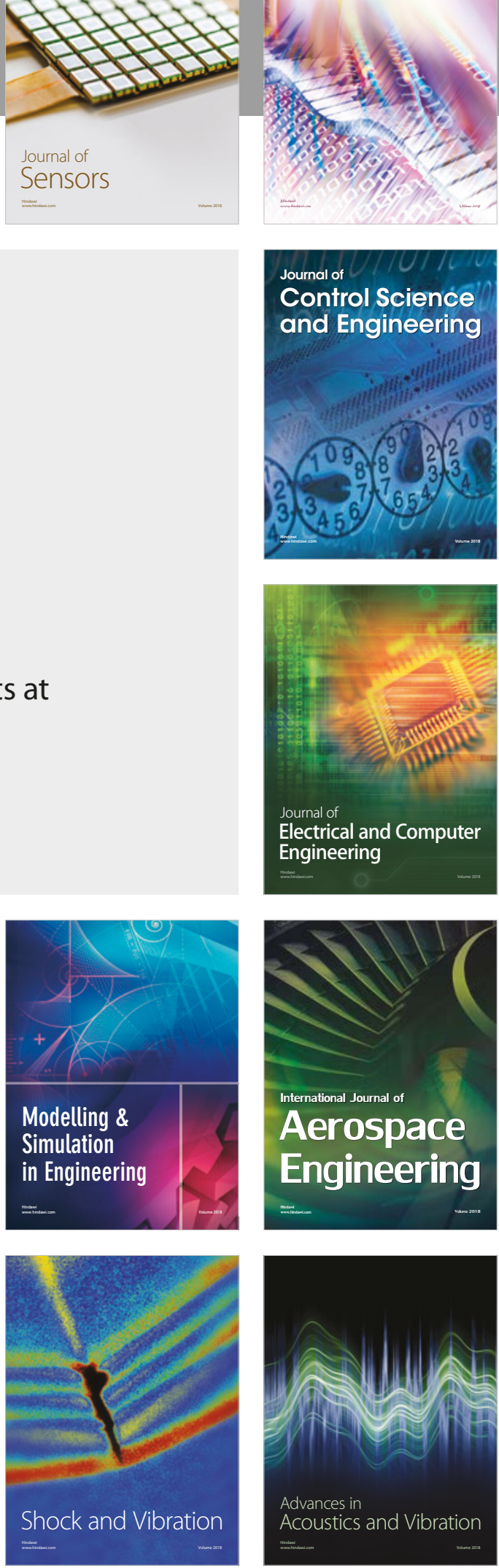